\title{
Glycine tomentella Hayata inhibits IL-1 $\beta$ and IL-6 production, inhibits MMP-9 activity, and enhances RAW264.7 macrophage clearance of apoptotic cells
}

\author{
Jia-Hau Yen ${ }^{1}$, Deng-Jye Yang ${ }^{2}$, Meng-Chi Chen ${ }^{1}$, Yu-Fan Hsieh ${ }^{1}$, Yu-Shu Sun ${ }^{4}$, Gregory J Tsay ${ }^{1,3^{*}}$
}

\begin{abstract}
Background: To assess the effects of Glycine tomentella Hayata (GTH), a traditional herbal medicine for treatment of rheumatic diseases on the expression of the proinflammatory cytokines and on the clearance of apoptotic cells by macrophages.

Methods: RAW264.7 cells were cultured with lipopolysaccharide (LPS) in the presence or absence of ethanol extract of GTH. The expression of proinflammatory cytokines IL-1 $\beta$, IL-6, and TNF- $\alpha$, and inducible nitric oxide synthase (iNOS) and transglutaminase 2 (TG2) were assayed by reverse transcriptase-polymerase chain reaction (RT-PCR) and enzyme-linked immunosorbent assay (ELISA). Matrix metalloproteinase (MMP)-2 and MMP-9 were assayed by gelatin zymography. For detecting uptake of apoptotic cells, RAW264.7 cells were cultured with carboxyfluorescein diacetate (CFDA)-stained apoptotic cells and assayed by flow cytometry.

Results: The major components of GTH analyzed by high-performance liquid chromatography (HPLC) chromatogram were daidzein (42.5\%), epicatechin (28.8\%), and naringin (9.4\%).

GTH treatment inhibited the expression of proinflammatory cytokines IL-1 $13, \mathrm{LL}-6$ and MMP-9 but did not affect the expression of TNF- $\alpha$ and iNOS. GTH significantly enhanced the expression of TG 2 and the clearance of apoptotic cells by RAW264.7 macrophages.

Conclusions: GTH inhibits proinflammatory cytokine secretion and MMP-9 activity, enhances apoptotic cell uptake and up-regulates TG2 expression. Our data show that GTH might have beneficial effects on rheumatic diseases.
\end{abstract}

\section{Background}

Glycine tomentella Hayata (GTH), also known as I-Tiao-Gung, is a plant of the soybean family. Root ethanol extracts of GTH have long been used as a traditional herbal medicine to treat a variety of rheumatic diseases, including rheumatoid arthritis (RA) and osteoarthritis (OA), in Kinmen, Taiwan [1-3]. Previous studies have documented an inhibitory effect of GTH on TNF- $\alpha$ expression by using a macrophage cell line of Atlantic salmon [2] and demonstrated analgesic and anti-inflammatory activities of the aqueous extract of GTH in mice [3]. GTH has also been reported to have anti-atherosclerotic effects and anti-oxidative activities $[1,4]$. However, the precise mechanism of the

\footnotetext{
* Correspondence: gjt@csmu.edu.tw

'Institute of Immunology, Chung Shan Medical University, Taichung, Taiwan Full list of author information is available at the end of the article
}

\section{-}

therapeutic effect of GTH on arthritis is not yet clear. It has not been investigated whether GTH affects the clearance of apoptotic cells or the production of matrix metalloproteinases (MMPs) and other proinflammatory cytokines.

RA is a common chronic inflammatory and destructive arthropathy characterized by the production of proinflammatory cytokines TNF- $\alpha$, IL- $1 \beta$, IL- 6 and MMPs [5]. The etiology of RA remains enigmatic. Although biologic therapies for RA have dramatically changed over the past 20 years, some patients still fail to respond to treatments. The need for better therapies is as important as ever.

This study investigates the possible pharmacological functions and immunomodulatory effects of GTH. We found that GTH suppressed the expression of proinflammatory cytokines and MMP-9 activity, enhanced apoptotic cell uptake and up-regulated TG2 expression.

(C) 2010 Yen et al; licensee BioMed Central Ltd. This is an Open Access article distributed under the terms of the Creative Commons Attribution License (http://creativecommons.org/licenses/by/2.0), which permits unrestricted use, distribution, and reproduction in any medium, provided the original work is properly cited. 


\section{Methods}

\section{Ethanol extraction of Glycine tomentella Hayata (GTH)}

GTH was a gift from the Kinmen Doctor Wang I-TiaoGung Company in Kinmen, Taiwan and authenticated by Professor Hsien-Cheh Chang of the China Medical University in Taiwan. The dry root of GTH (50 g) was grounded and extracted with $95 \%$ ethanol $(500 \mathrm{ml})$ at a ratio of 1: 10 (wt/vol) and refluxed for 2 hours at $75^{\circ} \mathrm{C}$ twice. After evaporation of the organic solvent under reduced pressure, followed by lyophilization at $32.8^{\circ} \mathrm{C}$, $3.7558 \mathrm{~g}$ of dry powder was obtained. The analytical equipments for the determination of flavonoids and phenolic acids in GTH by high performance liquid chromatography (HPLC) were a PrimeLine ${ }^{\mathrm{Tm}}$ Gradient Model 500G HPLC pump system (Analytical Scientific Instruments, Inc., El Sobrante, CA, USA) with an injection valve $(20 \mu \mathrm{L})$ (Rheodyne Inc., Cotati, CA, USA) and an S-3210 photodiode-array detector (PDA) (Schambeck SFD GmbH, Bad Honnef, Germany) [6].

\section{Cell culture of RAW264.7 cells}

RAW264.7 cells were purchased from Bioresource Collection and Research Center (HsinChu, Taiwan) and cultured in Dulbeco's Modified Eagle Medium (DMEM) containing $10 \%$ fetal bovine serum (Biological Industries, Kibbutz Beit Haemek, Israel), 2 mM glutamine,1 mM pyruvate, $1 \%$ non-essential amino acid,1000 $\mathrm{U} / \mathrm{ml}$ penicillin, $0.0025 \mathrm{mg} / \mathrm{ml}$ amphotericin, and $1 \mathrm{mg} / \mathrm{ml}$ streptomycin (Biological Industries).

\section{Cell viability}

Cell viability was assessed by the mitochondrial-dependent reduction of 3-(4,5-dimethylthiazol-2-yl)-2,5-diphenyl tetrazolium bromide (MTT) to purple formazan and cell death was determined with annexin $\mathrm{V}$ and propidium iodide staining. Cells were incubated with MTT (10\%) for 4 hours and formazan crystals were dissolved in Dimethyl Sulfoxide (DMSO). The converted dye was quantified by absorbance at $570 \mathrm{~nm}$. Measurement of early and late apoptosis was performed by flow cytometry using ANNEXIN V FITC KIT (AbD Serotec, Oxford, UK) according to the manufacture's instructions.

Reverse transcription-polymerase chain reaction (RT-PCR) Total RNA was isolated from RAW264.7 cells by using the Trizol reagent protocol (Sigma, St. Louis, MO, USA). Two micrograms of total RNA was denatured at $65^{\circ} \mathrm{C}$ with $1 \mu \mathrm{l}$ oligo-dT (Promega, Madison, WI, USA), and $4 \mu \mathrm{d}$ dNTPs $(10 \mathrm{mM})$ for 5 minutes in $12 \mathrm{ml}$ final volume. The primers-RNA mixture was cooled on ice, and $1 \mu$ Moloney Murine Leukemia Virus (M-MLV) reverse transcriptase (Invitrogen, Carlsbad, CA, USA), $1 \mu$ l RNase inhibitor (Promega) and $4 \mu \mathrm{l} 5 \times \mathrm{RT}$-buffer were added for a total volume of $20 \mathrm{ml}$. PCRs were performed under the following conditions: $94^{\circ} \mathrm{C}$ for 5 minutes, annealing at $54^{\circ} \mathrm{C}$ for 1 minute, and DNA synthesis at $72^{\circ} \mathrm{C}$ for 2 minutes, followed by 28 cycles. To assess the effects of GTH on the mRNA expression of TG2 of RAW264.7 cells by RT-PCR, RAW264.7 cells were incubated with GTH $(165 \mu \mathrm{g} / \mathrm{ml})$ for 24 hours before RT-PCR. The amplified PCR products were subjected to electrophoresis in a $2 \%$ agarose gel.

Sequences for the PCR primers: 5'-TCCATGAG CTTTGTACAAGGA-3', 5'-AGCCCATACTTTAGGAA GACA-3' (forward and reverse mouse IL-1 $\beta$ probe), 5'GTTCTCTGGGAAATCGTGGA-3', 5'-TGTACTCCA GGTAGCTA-3', (forward and reverse mouse IL-6 probe) 5'-TGATGACCGGGAGGACATCA-3', 5'-GATTC TCC AGGTAGAGATCTC-3' (forward and reverse mouse TG2 probe), 5'-ATGAGCACAGAAAGCATGATC-3', 5'-TA CAGGCTTGTCACTCGAATT-3' (forward and reverse mouse TNF- $\alpha$ probe), 5'-GCTCATGACATCGACCA GAA-3', 5'-ATCCACAACTCGCTCCAAGA-3' (forward and reverse mouse iNOS probe), 5'-TCACTCAA GATTGTCAGCAA-3', 5'-AGATCCACGACGGACA CATT-3' (forward and reverse mouse GAPDH probe).

\section{Gelatin-zymography}

To detect MMP-9 and MMP-2 activity, cell culture medium was collected and concentrated. Electrophoresis was performed using zymogram gelatin gels. Gelatin zymography was performed on a $10 \%$ sodium dodecyl sulfateacrylamide gel containing $0.1 \%$ gelatin (SIGMA), rinsed in dd-H2O followed by incubation with bulky volume of renaturation buffer $(2.7 \% \mathrm{TX}-100$ in dd-H2O) at room temperature for one hour with gentle shaking. The enzyme activity was developed in $50 \mathrm{mM}$ Tris ph7.5, 0.2 $\mathrm{M} \mathrm{NaCl}, 5 \mathrm{mM} \mathrm{CaCl} 2$ and $0.2 \% \mathrm{Brij} 35$ at $37^{\circ} \mathrm{C}$ for 24 hours and stained with Coomassie Blue. MMP-9 and MMP-2 activity levels were normalized to that for $\beta$ actin. Images were obtained with an Alpha-Imager 2200.

\section{Phagocytosis assay}

The human keratinocyte cell line (HaCat) was a gift from Professor Jen-Hung Yang of the Department of Dermatology at Chung Medical University in Taichung, Taiwan. For induction of UV-induced apoptosis, HaCat cells were exposed to UV radiation at $1650 \mathrm{~J} / \mathrm{m}^{2}$ by using the Spectroline UV Crosslinker with the Auto crosslink mode (Spectroline, New York, NY, USA). For phagocytosis of apoptotic cells, the UV-irradiated HaCat cells were labeled with carboxy-fluorescein diacetate (CFDA) followed by incubation with RAW264.7 cells at 10:1 target/macrophage ratio at $4^{\circ} \mathrm{C}$ for 4 hours. RAW264.7 cells were incubated with carboxylate-modified latex beads (Sigma, St. Louis, MO, USA) were used as the control. After washing, the cells on the dish were 
resuspended in Phosphate Buffer Saline (PBS) solution and 10,000-20,000 cells were analyzed for fluorescence intensity by flow cytometry. The phagocytosis index was calculated as the number of ingested beads or apoptotic cells divided by the total number of macrophages.

\section{Statistics}

The data were analyzed with GraphPad Prism 4 software by one-way analysis of variance (one-way ANOVA) to determine the significance between sets of categorical data. A p-value of $<0.05$ was considered to be significant.

\section{Results}

\section{Contents of phytochemicals in GTH}

The ethanol extract of GTH was analyzed by HPLC. Three phenolic acids including chlorogenic, ferulic and sinapic acids, and 11 flavonoids including catechin, epicatechin, naringin, riodictyol, daidzein, glycitein, narigenin, luteolin, genistein, hesperetin, and isorhamnetin could be determined in GTH. The major components of GTH were daidzein (42.5\%), epicatechin (28.8\%), and naringin (9.4\%) (Figure 1A). The three components constituted $80.8 \%$ of the total GTH (Table 1 and Figure 1A).

\section{Cell viability}

To assess the suitable concentration of GTH for the study, RAW264.7 cells were incubated with GTH at concentrations ranging from 20 to $330 \mu \mathrm{g} / \mathrm{ml}$ and cell viability was measured by MTT test 24 hours later. We found that at a concentration of $330 \mu \mathrm{g} / \mathrm{ml}$, cell viability was reduced by $20 \%$ compared to the controls (Figure

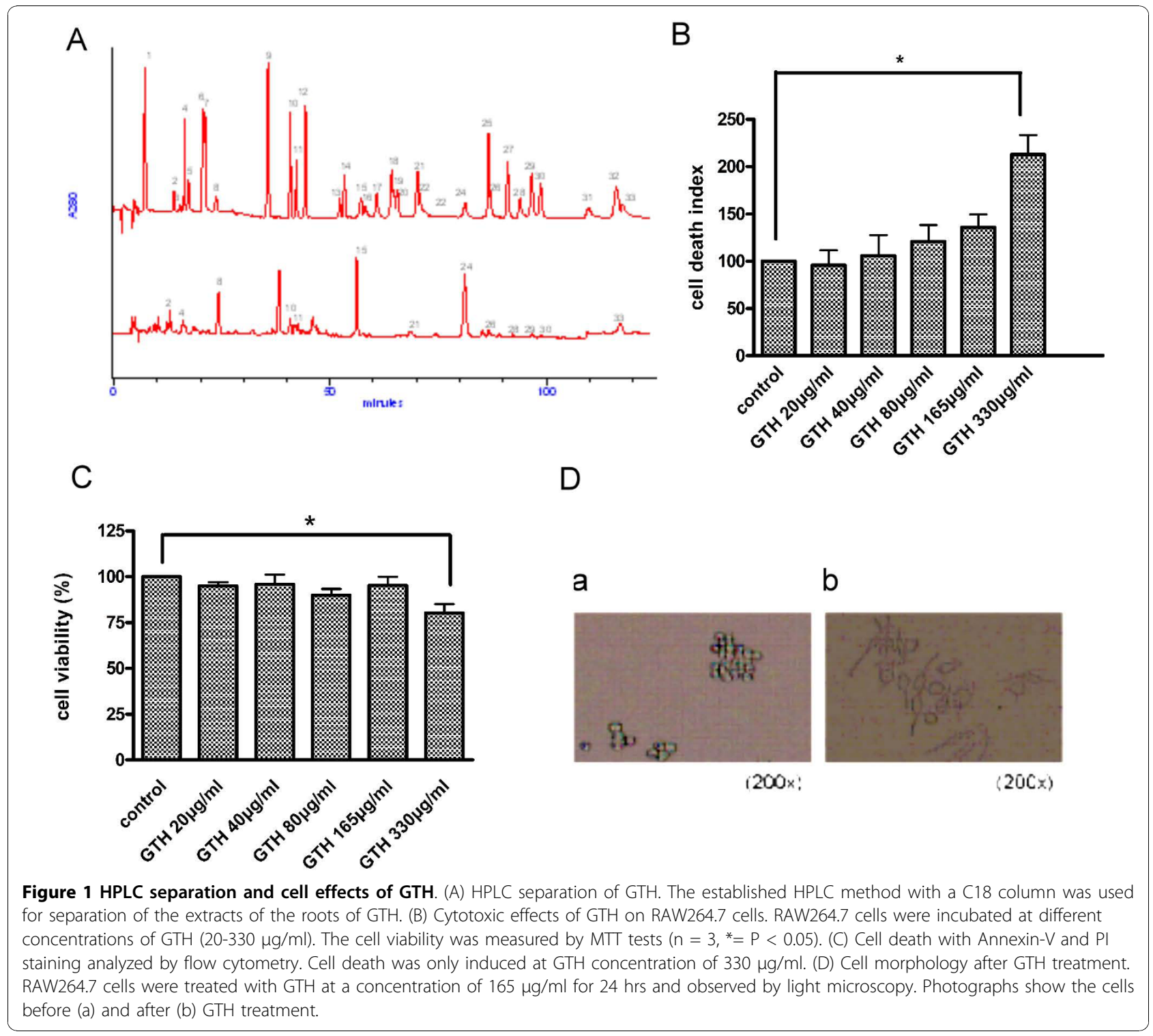


Table 1 Content of flavonoids and phenolic acids in the ethanol extract of Glycine tomentella Hayata.3

\begin{tabular}{|c|c|c|c|c|c|c|c|}
\hline $\begin{array}{l}\text { Peak } \\
\text { no. }\end{array}$ & Compound & $\begin{array}{l}\text { retention time } \\
\text { (min) }\end{array}$ & $\begin{array}{l}\text { amount }(\mathrm{mg} / \mathrm{g} \\
\text { extract) }\end{array}$ & $\begin{array}{l}\text { Peak } \\
\text { no. }\end{array}$ & compound & $\begin{array}{l}\text { etention time } \\
\text { (min) }\end{array}$ & $\begin{array}{l}\text { amount (mg/g } \\
\text { extract) }\end{array}$ \\
\hline 1 & Gallic acid & 7.59 & $\mathrm{ND}$ & 18 & $\begin{array}{l}\text { Rosmarinic } \\
\text { acid }\end{array}$ & 65.73 & ND \\
\hline 2 & Catechin & 14.35 & $2.59 \pm 0.10$ & 19 & Quercitrin & 66.20 & ND \\
\hline 3 & Gentisic acid & 15.65 & ND & 20 & Neohesperidin & 67.28 & ND \\
\hline 4 & Chlorogenic acid & 16.81 & $0.60 \pm 0.04$ & 21 & Eriodictyol & 72.09 & $0.13 \pm 0.01$ \\
\hline 5 & $\begin{array}{l}\text { p-Hydroxy benzoic } \\
\text { acid }\end{array}$ & 17.86 & ND & 22 & Diosmin & 72.54 & ND \\
\hline 6 & Vanillic acid & 21.25 & ND & 23 & Morin & 73.69 & ND \\
\hline 7 & Caffeic acid & 21.67 & ND & 24 & Daidzein & 83.23 & $12.02 \pm 0.82$ \\
\hline 8 & Epicatechin & 24.54 & $8.16 \pm 0.22$ & 25 & Quercetin & 88.05 & ND \\
\hline 9 & p-Cumeric acid & 36.63 & ND & 26 & Glycitein & 88.56 & $0.10 \pm 0.01$ \\
\hline 10 & Ferulic acid & 41.64 & $0.46 \pm 0.12$ & 27 & Narigenin & 92.77 & ND \\
\hline 11 & Sinapic acid & 43.04 & $0.42 \pm 0.13$ & 28 & Luteolin & 95.73 & $0.10 \pm 0.01$ \\
\hline 12 & Syringic acid & 45.19 & ND & 29 & Genistein & 98.54 & $0.11 \pm 0.01$ \\
\hline 13 & Rutin & 53.28 & ND & 30 & Hesperetin & 100.68 & $0.17 \pm 0.01$ \\
\hline 14 & p-Anisic acid & 54.52 & ND & 31 & Kamempferol & 112.34 & ND \\
\hline 15 & Naringin & 58.50 & $2.68 \pm 0.09$ & 32 & Apigenin & 118.91 & ND \\
\hline 16 & Myricetin & 59.58 & ND & 33 & Isorhamnetin & 119.80 & $0.69 \pm 0.02$ \\
\hline 17 & Hesperidin & 62.33 & ND & Total & & & 28.26 \\
\hline
\end{tabular}

a. All values are mean \pm SD obtained by triplicate analyses.

b. ND = not detected.

$1 \mathrm{~B} ; \mathrm{p}<0.05)$. The cell viability at GTH concentration of $20-165 \mu \mathrm{g} / \mathrm{ml}$ was no difference from that of the untreated controls. Figure $1 \mathrm{C}$ shows that cell death was induced at GTH concentration of $330 \mu \mathrm{g} / \mathrm{ml}$ by Annexin-V and PI staining. Therefore, the maximum concentration of $165 \mu \mathrm{g} / \mathrm{ml}$ was used for further experiments. After 24 hours of GTH treatment, the cells were observed under light microscope. The cell morphology had changed and their membranes had developed protrusions or processes which were in striking contrast to the round cells of the untreated controls (Figure 1D). The changes in cell morphology suggest activation of the cells by GTH stimulation.

\section{GTH regulates mRNA expression of proinflammatory cytokines}

To determine whether GTH affects the expression of proinflammatory cytokines, RAW264.7 cells were pretreated with GTH at 20, 40, 80 and $165 \mu \mathrm{g} / \mathrm{ml}$ for 24 hours, followed by stimulation with LPS $(10 \mathrm{ng} / \mathrm{ml})$ for 4 hours. The mRNA expression was detected by RT-PCR (Figure 2A). GTH significantly reduced the expression of IL- $1 \beta$ and IL- 6 by up to $55 \%$ and $56 \%$, respectively (Figure 2B-C). However, GTH did not affect the mRNA expression of TNF- $\alpha$ and iNOS (Figure 2D-E). The inhibitory effect of GTH on IL- $1 \beta$ and IL- 6 was exerted in a dosedependent manner. In parallel, the experiments were also performed by using the human monocyte cell line U937 and we found that U937 cells pre-treated with GTH also decreased the expression of IL-6 mRNA in a dose-dependent manner (data not shown).

\section{GTH inhibits the production of IL-1 $\beta$ and IL- 6}

RAW264.7 cells were incubated with GTH at 20, 40, 80 and $165 \mu \mathrm{g} / \mathrm{ml}$ for 24 hours before stimulation with $10 \mathrm{ng} / \mathrm{ml}$ LPS. The supernatants were collected 12 hours later and the cytokines were analyzed by ELISA. Consistent with the results that GTH treatment suppressed mRNA expression of proinflammatory cytokines by RT-PCR, the production of IL- $1 \beta$ and IL- 6 were significantly decreased by GTH treatment (Figure 3A-B). In a dose-dependent manner, GTH at a concentration of $165 \mu \mathrm{g} / \mathrm{ml}$ inhibited IL- $1 \beta$ and IL-6 secretion by up to $93.2 \%$ and $79 \%$, respectively. This data indicate that GTH is a potent inhibitor of IL-1 $\beta$ and IL-6. On the contrary, GTH did not reduce the expression and the production of TNF- $\alpha$ (Figure 3C).

\section{GTH down-regulates MMP expression}

To determine whether the ethanol extract of GTH affects the activity of MMPs in LPS-stimulated macrophages, RAW264.7 cells were incubated with different concentrations of $\mathrm{GTH}$, followed by stimulation with LPS as described and the activity of MMP-2 and MMP-9 was analyzed by gelatin zymography. We found the activity of MMP-9, but not MMP-2, was significantly inhibited by GTH treatment in a dosedependent manner (Figure 4A-B). 


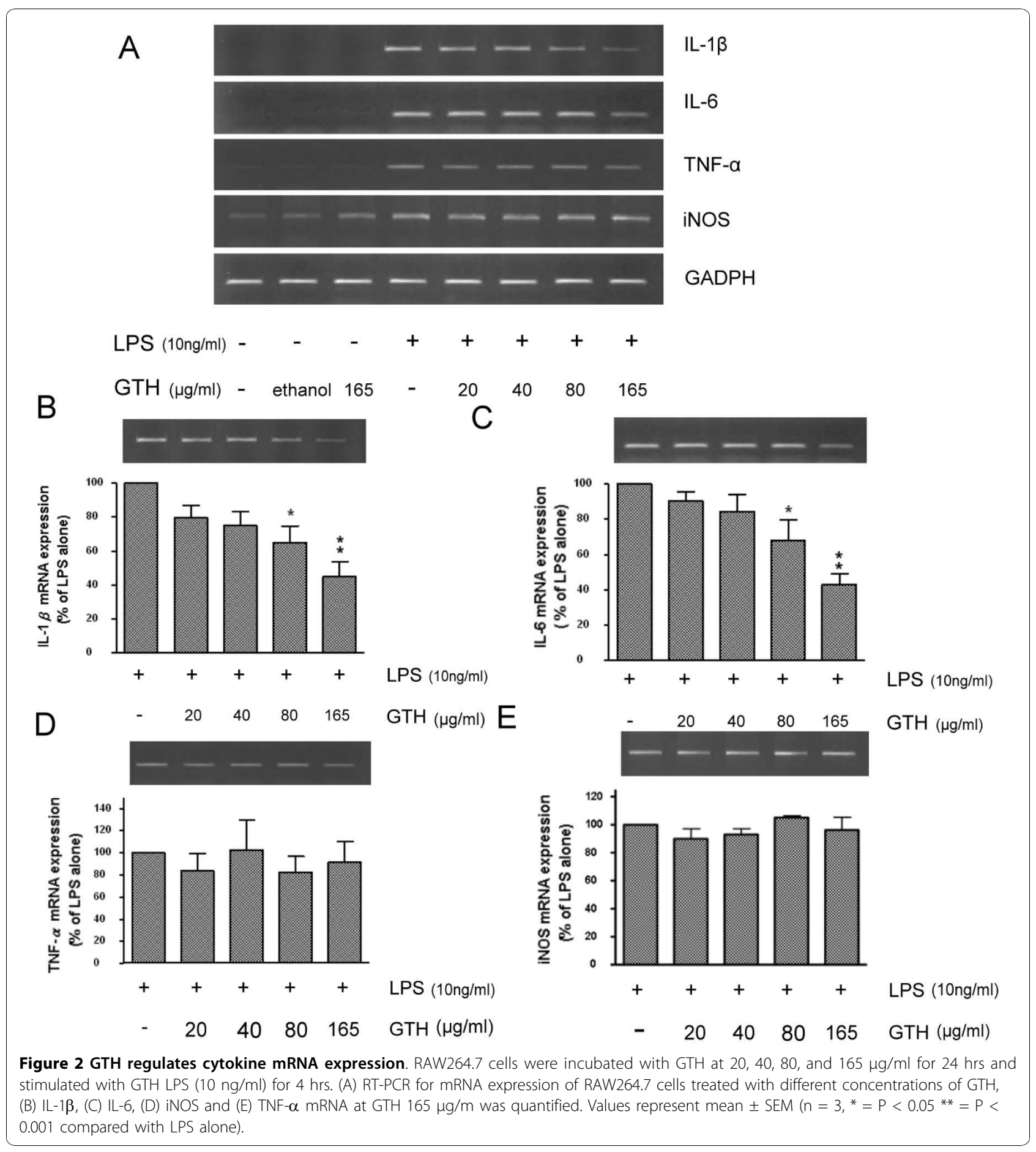

\section{GTH enhances clearance of apoptotic cells and the expression of TG2}

The findings that GTH down-regulated the expression and production of IL-1 $\beta$, IL- 6 and MMP-9 suggest that GTH may play a role in tuning down inflammatory responses. We further investigated whether $\mathrm{GTH}$ also plays a role in the clearance of apoptotic cells. Apoptotic cells were generated by UV irradiation of the keratinocyte cell line HaCat. The phagocytosis of the apoptotic cells by GTH-pretreated RAW264.7 cells was observed after a 4 hour co-culture by both light microscopy (Figure 5A) and by fluorescent microscopy (Figure 5B). In parallel, the phagocytic activity of macrophages was also detected with flow cytometry which showed that GTH strongly 
A

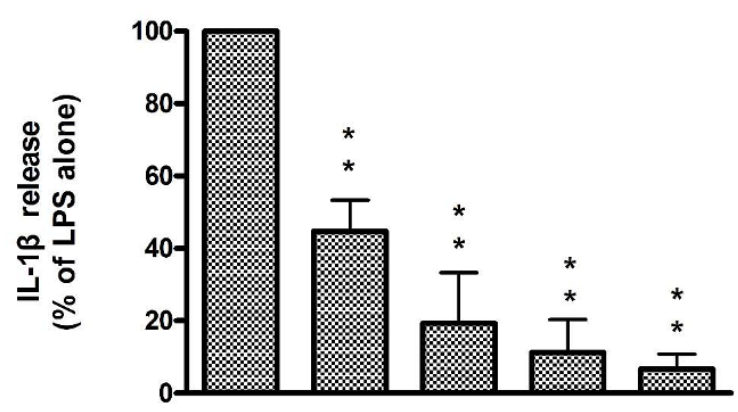

B

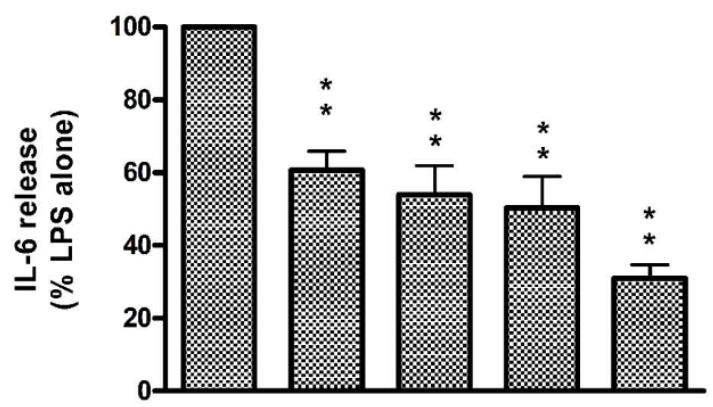

C

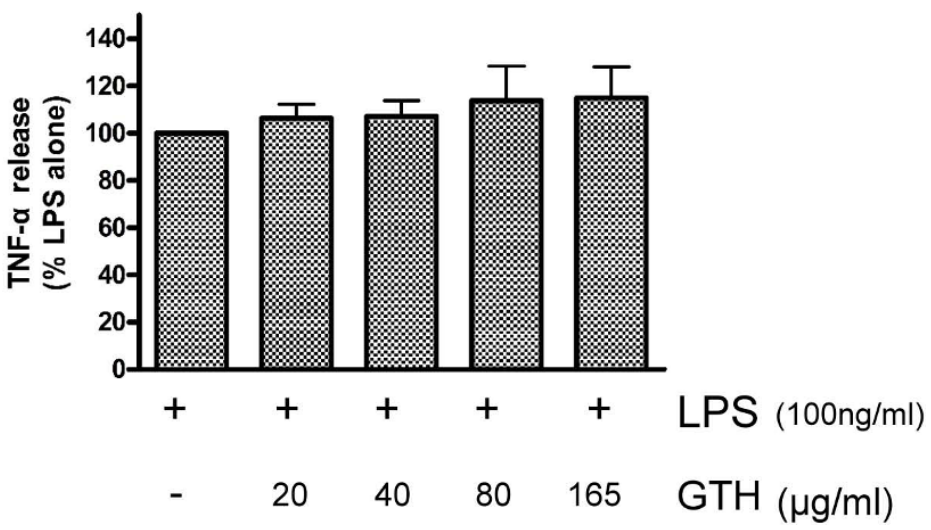

Figure 3 GTH regulates cytokine protein production. RAW264.7 cells were incubated and stimulated as described. Culture supernatant was analyzed by ELISA for (A) IL-1 $\beta,(B) I L-6$, and (C) TNF- $\alpha$. Values represent mean \pm SEM ( $n=3,{ }^{* *}=P<0.001$ compared with LPS alone).

enhanced the macrophage clearance of apoptotic cells (Figure 5C). However the uptake of latex beads was not affected by GTH treatment (Figure 5D). To explore further the possible mechanism of the enhanced apoptotic cell clearance after GTH treatment, mRNA of GTHtreated RAW264.7 cells was analyzed for TG2 expression and a significantly increased TG2 mRNA expression was found in GTH-treated cells (Figure 5E).

\section{Discussion}

Root extracts of GTH have long been used as a traditional herbal medicine to treat arthritis in Taiwan. GTH is also used as a functional tea, steeped wine and skin patch for commercial purposes because of its health advantages. In the present study, we demonstrated that the therapeutic effects of the ethanol extract of GTH on anti-proinflammatory cytokines are due to the suppression of IL-1 $\beta$, IL-6 and MMP-9 activity. Previous studies documented that GTH has anti-inflammatory and analgesic activities [2,3]. The results of our study confirm and extend previous findings that GTH has immunomodulatory effects.

Recently, Chuang et al [2] reported that GTH could inhibit TNF-a in a macrophage cell line of Atlantic salmon but did not inhibit IL-1 $\beta$. In contrast, we found that GTH could strongly inhibit IL- 6 and IL-1 1 , but not TNF-a. The discrepancy of the effects of GTH may be due to the fact that the experiments used different cell lines and experimental systems. We pre-treated with GTH for 24 hours, then added LPS at a concentration of 


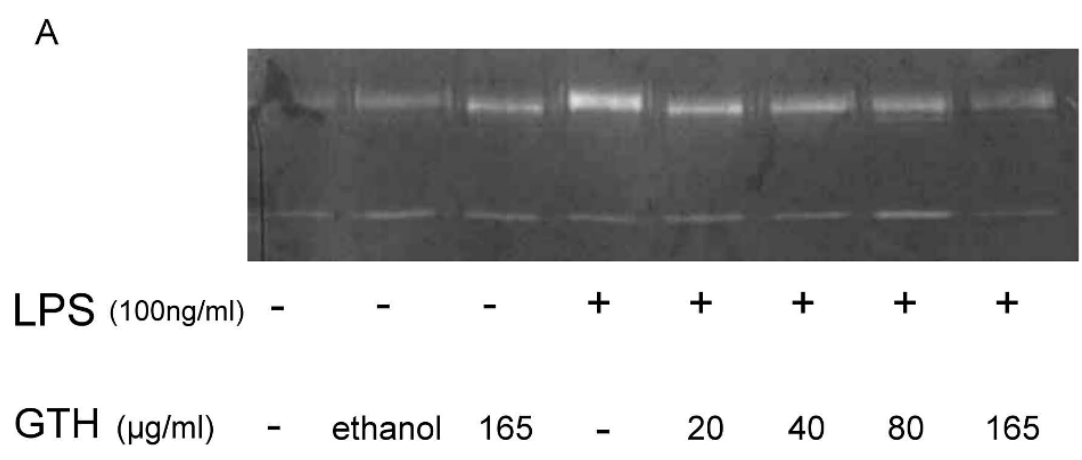

B

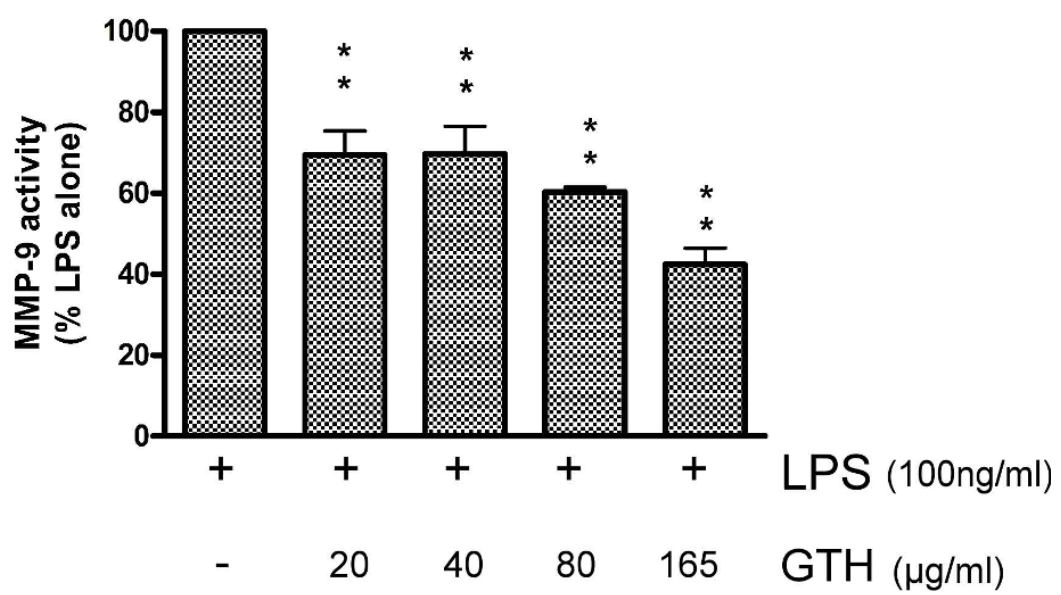

Figure $4 \mathrm{GTH}$ modulates the activity of matrix metalloproteinase. RAW264.7 cells were incubated with different concentrations of GTH for 24 hrs, followed by stimulation with LPS. The activity of (A) MMP-9 and (B) MMP-2 was analyzed by gelatin zymography after 12-hr LPS stimulation. Values represent mean $\pm \operatorname{SEM}\left(n=3,{ }^{* *}=P<0.001\right.$ compared with LPS alone).

$10 \mathrm{ng} / \mathrm{ml}$ and $100 \mathrm{ng} / \mathrm{ml}$ for 2 hours and analyzed the cytokines by RT-PCR and ELISA. In contrast, Chuang et al had co-cultured GTH with LPS at a concentration of 2 $\mathrm{mg} / \mathrm{ml}$ and analyzed the cytokines with real-time PCR. The discrepant effect of GTH on TNF-a need to be further clarified. Previous studies also demonstrated that daidzein decreased NO production in LPS-stimulated RAW264 cells [7] and inhibited iNOS expression and NO production in murine J774 cell line[8]. However, these studies were performed with individual and purified daidzein. According to the HPLC analysis, there are many different isoflavones in the extract of GTH. The effect of GTH may be different from that of the purified compounds. The discrepancies among these studies might also be caused by species differences.

It is interesting to note that the therapeutic range of GTH concentration for suppressing cytokines was relatively small. The viability of RAW264.7 cells was affected at GTH concentration of $330 \mathrm{mg} / \mathrm{ml}$. While the effects of GTH on IL-1 $\beta$, IL- 6 and MMP-9 were seen at a lower concentration of $20 \mathrm{mg} / \mathrm{ml}$, the effects of GTH on phagocytosis of apoptotic cells did not become apparent until the concentration of $165 \mathrm{mg} / \mathrm{ml}$ was used.

MMPs are involved in several pathological processes including cancers, inflammation and arthritis. Among the MMPs, MMP-9 has been shown to be involved in a variety of pathological processes of autoimmune diseases. MMP-9 secreted by macrophages regulates leukocyte migration in inflammatory diseases [9]. MMP-9 has also been shown to play an important role in cartilage degradation [9] and angiogenesis [10]. Our findings that GTH inhibit the activity of MMP-9 suggest the potential effect of GTH in mitigating the destruction of cartilage and inflammation of rheumatic diseases.

Recently, phagocytosis of apoptotic cells, also called efferocytosis, has attracted much attention because phagocyte clearance of apoptotic cells appears to be critical in the resolution of inflammation [11-13]. The ingestion of apoptotic cells by inflammatory macrophages also promotes the synthesis and release of anti-inflammatory mediators such as TGF-b1 and IL-10 [14-16]. By 


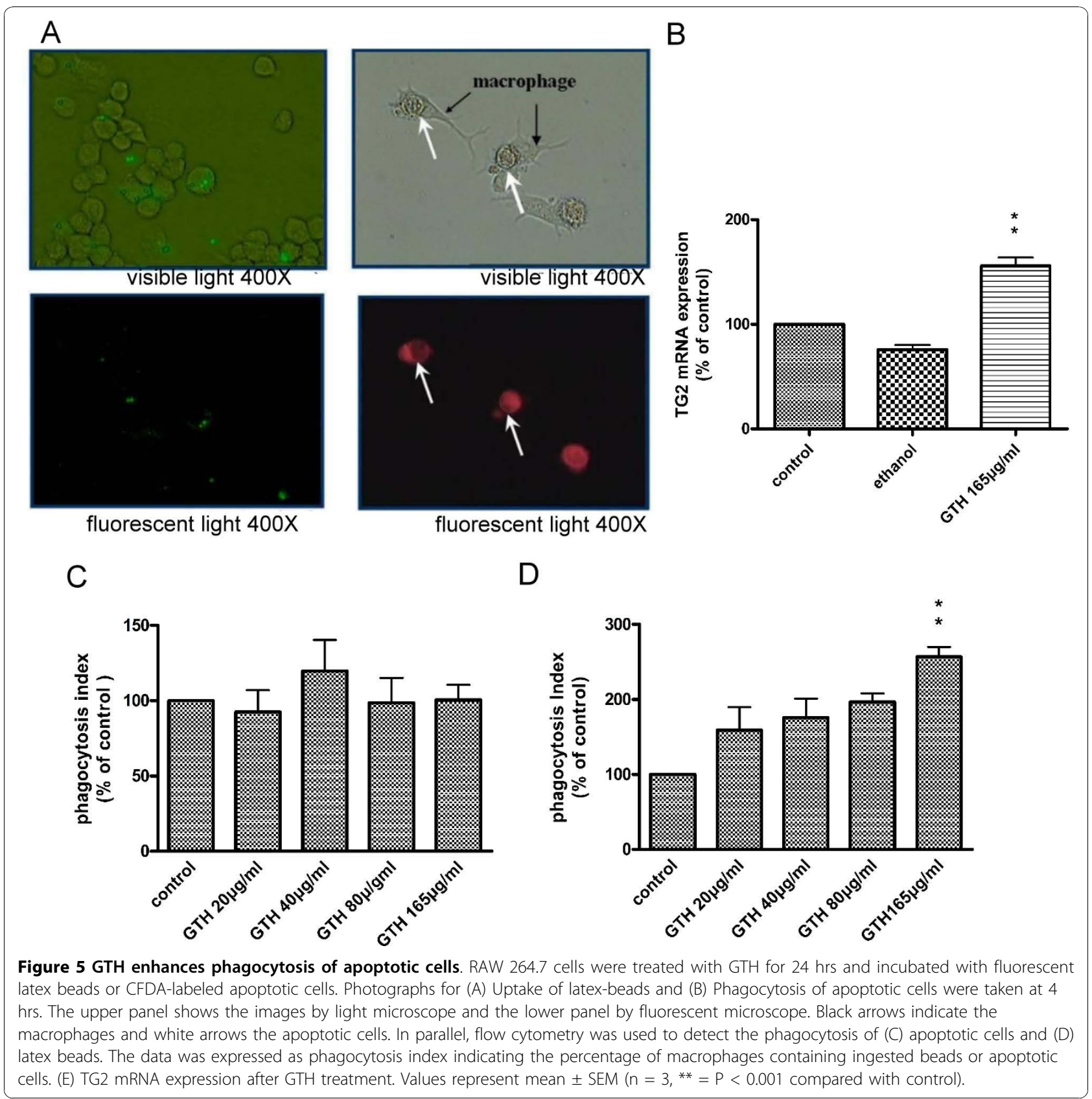

enhancing the clearance of apoptotic cells, GTH may be effective in resolving inflammation in arthritis.

Our results were identical to previous studies [4] that indicated that isoflavones, especially daidzein, were the effective components in G. tomentella. However, our study found that epicatechin and naringin were also the major compounds (flavonoids) in GTH in addition to daidzein. Moreover, there were few phenolic acids (chlorogenic, ferulic and sinapic acids) found in GTH.

\section{Conclusions}

In conclusion, this study demonstrates that GTH enhances the clearance of apoptotic cells and is a potent IL-1 $\beta$, IL- 6 and MMP-9 inhibitor. These findings may explain the anti-inflammatory effects of GTH.

\section{Abbreviations Used}

(GTH): Glycine tomentella Hayata; (TG2): Transglutaminase 2; (RA): Rheumatoid arthritis; (OA): Osteoarthritis; (MMPs): Metalloproteinases 


\section{Acknowledgements}

The investigators would like to thank the Doctor Wang I-Tiao-Gung Company in Kinmen, Taiwan for providing Glycine tomentella Hayata for this study. This study was supported by grants NSC-95-2745-B-040-007-URD and NSC-96-2314-B-040-013-MY3 from the National Science Council, Taiwan. Flow cytometry was performed in the Instrument Center of Chung Shan Medical University, which is supported by National Science Council, Ministry of Education and Chung Shan Medical University.

\section{Author details}

'Institute of Immunology, Chung Shan Medical University, Taichung, Taiwan. ${ }^{2}$ School of Health Diet and Industry Management, Chung Shan Medical University, Taichung, Taiwan. ${ }^{3}$ Department of Internal Medicine, Chung Shan Medical University Hospital, Taichung, Taiwan. ${ }^{4}$ Department of Clinical Laboratory Chung Shan Medical University Hospital, Taichung, Taiwan.

\section{Authors' contributions}

GJT initiated the concept and design of the study and collected, analyzed, and interpreted the data and prepared the manuscript. JHY, DJY, MCC, YFH, and YSS... collected the data. All authors read and approved the final manuscript.

\section{Competing interests}

The authors declare that they have no competing interests.

Received: 20 August 2010 Accepted: 5 November 2010

Published: 5 November 2010

\section{References}

1. Sun Pan B, Kuo YY, Chen TY, Liu YC: Anti-oxidative and anti-inflammatory activities of two different species of a Chinese herb I-Tiao-Gung. Life Sci 2005, 77(22):2830-9.

2. Chuang WL, Haugland O, Pan BS, Evensen O: Isoflavone-rich extracts from wooly glycine Glycine tomentella inhibits LPS-induced TNF-alpha expression in a macrophage cell line of Atlantic salmon (Salmo salar L.). Mol Immunol 2008, 45(15):3956-64.

3. Lu TC, Ko YZ, Huang HW, Hung YC, Lin YC, Peng WH: Analgesic and antiinflammatory activities of aqueous extract from Glycine tomentella root in mice. J Ethnopharmacol 2007, 113(1):142-8.

4. Chen TY, Pan BS: Ex vivo inhibitory effect on tilapia LDL oxidation and hypolipidemia properties of Glycine tomentella root extract. Comp Biochem Physiol A Mol Integr Physiol 2007, 148(1):189-95.

5. Choy EH, Panayi GS: Cytokine pathways and joint inflammation in rheumatoid arthritis. N Engl J Med 2001, 344(12):907-16.

6. Jau-Tien Lin, Shih-Chuan Liu, Gregory JTsay, Deng-Jye Yang: Composition of flavonoids and phenolic acids in Glycin tomentella Hayata cultivated in various soils. Food Chemistry 2010, 121(3):659-665,.

7. Wang J, Mazza G: Inhibitory effects of anthocyanins and other phenolic compounds on nitric oxide production in LPS/IFN-gamma-activated RAW 264.7 macrophages. J Agric Food Chem 2002, 50(4):850-7.

8. Hamalainen M, Nieminen R, Vuorela P, Heinonen M, Moilanen E: Antiinflammatory effects of flavonoids: genistein, kaempferol, quercetin, and daidzein inhibit STAT-1 and NF-kappaB activations, whereas flavone, isorhamnetin, naringenin, and pelargonidin inhibit only NF-kappaB activation along with their inhibitory effect on iNOS expression and NO production in activated macrophages. Mediators Inflamm 2007, 45673.

9. Ram M, Sherer Y, Shoenfeld Y: Matrix metalloproteinase-9 and autoimmune diseases. J Clin Immunol 2006, 26(4):299-307.

10. Vu TH, Shipley JM, Bergers G, Berger JE, Helms JA, Hanahan D, Shapiro SD, Senior RM, Werb Z: MMP-9/gelatinase $B$ is a key regulator of growth plate angiogenesis and apoptosis of hypertrophic chondrocytes. Cell 1998, 93(3):411-22

11. Savill J, Dransfield I, Gregory C, Haslett C: A blast from the past: clearance of apoptotic cells regulates immune responses. Nat Rev Immunol 2002, 2(12):965-75.

12. Savill J, Fadok V: Corpse clearance defines the meaning of cell death. Nature 2000, 407(6805):784-8

13. Fadok VA, Bratton DL, Konowal A, Freed PW, Westcott JY, Henson PM: Macrophages that have ingested apoptotic cells in vitro inhibit proinflammatory cytokine production through autocrine/paracrine mechanisms involving TGF-beta, PGE2, and PAF. J Clin Invest 1998, 101(4):890-8.

14. Gilroy DW, Lawrence T, Perretti M, Rossi AG: Inflammatory resolution: new opportunities for drug discovery. Nat Rev Drug Discov 2004, 3(5):401-16.

15. Savill J: Apoptosis in resolution of inflammation. J Leukoc Biol 1997, 61(4):375-80.

16. Chung EY, Liu J, Homma Y, Zhang Y, Brendolan A, Saggese M, Han J, Silverstein R, Selleri L, Ma X: Interleukin-10 expression in macrophages during phagocytosis of apoptotic cells is mediated by homeodomain proteins Pbx1 and Prep-1. Immunity 2007, 27(6):952-64.

doi:10.1186/1423-0127-17-83

Cite this article as: Yen et al: Glycine tomentella Hayata inhibits IL-1 $\beta$ and IL-6 production, inhibits MMP-9 activity, and enhances RAW264.7 macrophage clearance of apoptotic cells. Journal of Biomedical Science 2010 17:83.

\section{Submit your next manuscript to BioMed Central and take full advantage of:}

- Convenient online submission

- Thorough peer review

- No space constraints or color figure charges

- Immediate publication on acceptance

- Inclusion in PubMed, CAS, Scopus and Google Scholar

- Research which is freely available for redistribution
Ciomed Central 